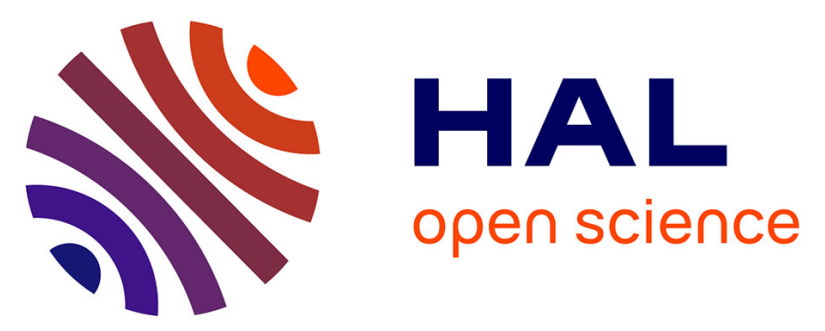

\title{
Water Flow and Dissolved Mn Alter Transformation of Pipemidic Acid by Manganese Oxide
}

\author{
Rasesh Pokharel, Qinzhi Li, Lian Zhou, Khalil Hanna
}

\section{To cite this version:}

Rasesh Pokharel, Qinzhi Li, Lian Zhou, Khalil Hanna. Water Flow and Dissolved Mn Alter Transformation of Pipemidic Acid by Manganese Oxide. Environmental Science and Technology, 2020, 54 (13), pp.8051-8060. 10.1021/acs.est.0c01474 . hal-02890116

\section{HAL Id: hal-02890116 https://hal.science/hal-02890116}

Submitted on 9 Jul 2020

HAL is a multi-disciplinary open access archive for the deposit and dissemination of scientific research documents, whether they are published or not. The documents may come from teaching and research institutions in France or abroad, or from public or private research centers.
L'archive ouverte pluridisciplinaire HAL, est destinée au dépôt et à la diffusion de documents scientifiques de niveau recherche, publiés ou non, émanant des établissements d'enseignement et de recherche français ou étrangers, des laboratoires publics ou privés. 


4

\section{Water flow and dissolved $\mathrm{Mn}^{\mathrm{II}}$ alter transformation of pipemidic acid by manganese oxide}

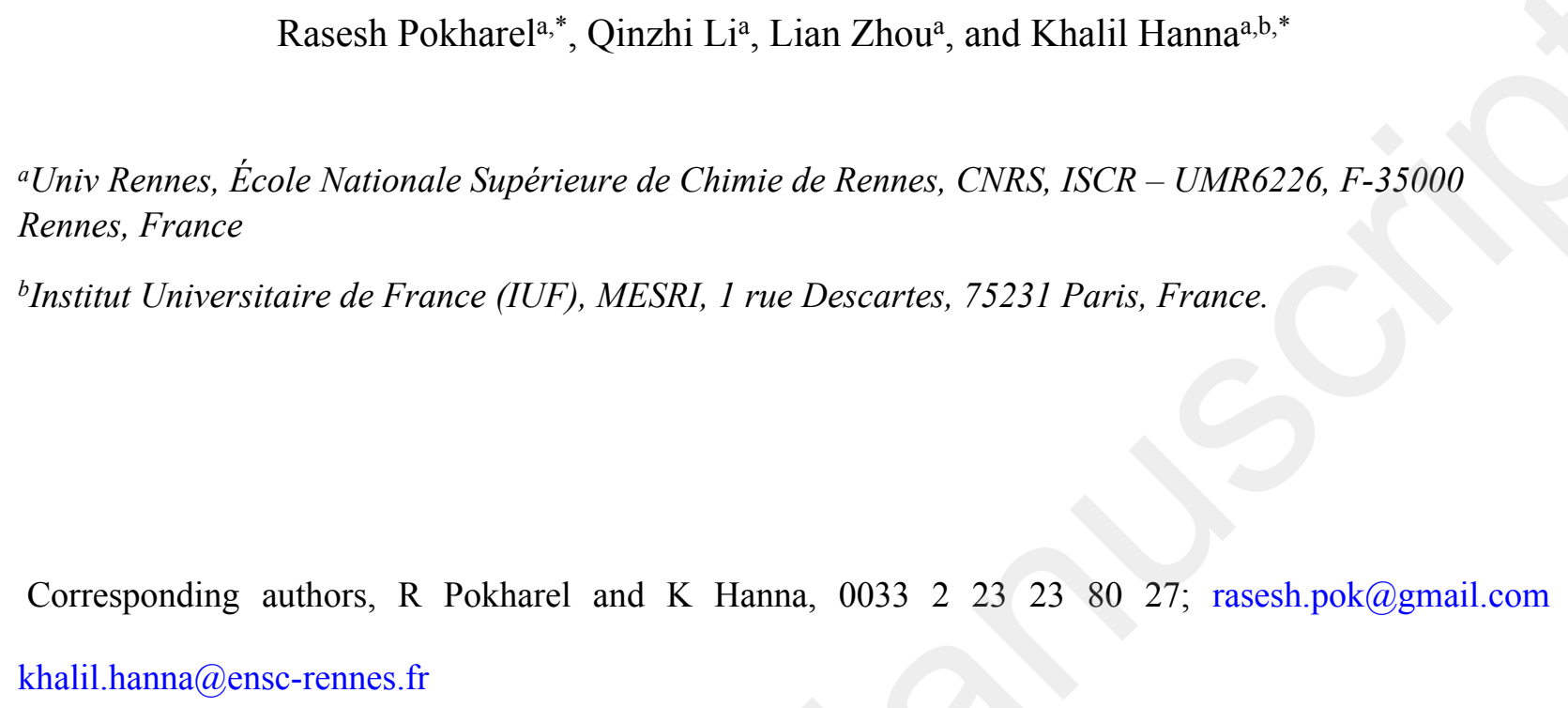

Corresponding authors, R Pokharel and K Hanna, 00332232380 27; rasesh.pok@gmail.com khali1.hanna@ensc-rennes.fr

(1)

1




\section{Abstract}

25 Manganese oxides have been proposed as a promising geomedia to remove trace organic contaminants in both natural soils and artificial infiltration systems. Although $\mathrm{MnO}_{\mathrm{x}}$-based redox

27 processes have been largely investigated, little is known on the effects of water flow and dissolved $28 \mathrm{Mn}^{\mathrm{II}}$ on manganese-mediated redox reactions in saturated porous media. Here, we have 29 demonstrated that the reactive transport of a widely used quinolone antibiotic, pipemidic acid (PIP), 30 in $\mathrm{MnO}_{2}$-coated sand (MCS) columns is altered by the presence of dissolved $\mathrm{Mn}^{\mathrm{II}}$, in situ generated 31 as reduced ions or present in inflow solution. Decreasing flow rate or flow interruption facilitated 32 oxidation reaction and generated redox byproducts $\left(\mathrm{Mn}^{\mathrm{II}}\right.$ and $\left.\mathrm{PIP} \mathrm{Px}_{\mathrm{ox}}\right)$. However, preloading of MCS 33 columns with dissolved $\mathrm{Mn}^{\mathrm{II}}$ led to suppressed reactivity with PIP. When PIP and $\mathrm{Mn}^{\mathrm{II}}$ are 34 simultaneously injected, competition between PIP and $\mathrm{Mn}^{\mathrm{II}}$ for binding at the edge sites takes place 35 during the initial kinetic phase of reaction, while at later breakthrough time $\mathrm{Mn}^{\mathrm{II}}$ will occupy both edge and vacancy sites due to continuous supply of $\mathrm{Mn}^{\mathrm{II}}$. We also developed a reactive transport

37 model that accounts for adsorption kinetics to predict changes in transport behavior of antibiotics in presence of different doses of dissolved $\mathrm{Mn}^{\mathrm{II}}$. This work has strong implications for an accurate 39 assessment of reactivity of manganese oxides used as an engineered geomedia for quinolones 40 remediation and in developing transport models of antibiotics in natural systems.

\section{$41 \quad$ TOC/Abstract art}

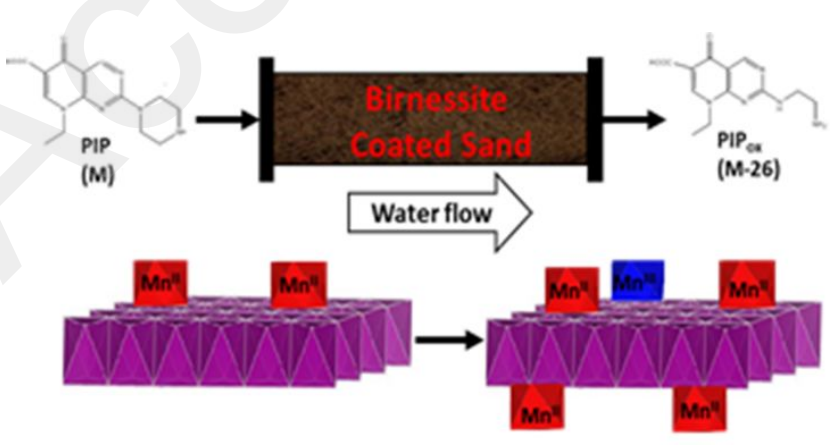


43

\section{Introduction}

The widespread occurrence of pharmaceuticals (e.g. quinolone antibiotics) in nature is an emerging global threat with alarming consequences on public health (e.g. multiple antimicrobial resistance has emerged as one of the serious health threats of the 21 st century) ${ }^{1}$ and water resources quality. ${ }^{2-4}$ The use of recycled sewage sludge (which contain antibiotics up to several $\mathrm{mg} / \mathrm{L}$ ) ${ }^{5}$ by farmers globally as fertilizers for agricultural practices, further increases the chances of their reentry to humans/animals through soil-groundwater route. As a result, antibiotics have been detected in food and different water reservoirs such as surface, ground and drinking water at concentration levels ranging from $\mathrm{ng} / \mathrm{L}$ to $\mathrm{mg} / \mathrm{L} .^{6}$

The fate and transport of quinolones in aquatic and terrestrial systems are strongly related to their interactions with environmental mineral surfaces. Among redox-sensitive minerals, manganese species can be found as oxides and/or hydroxides in the form of coatings on other particles and/or as nodules of various diameters. ${ }^{7}$ Manganese oxides are less abundant in comparison to Fe-oxyhydroxides but have higher redox potential. ${ }^{8}$ Studies have shown that layered manganese oxide (also known as birnessite), one of the most common manganese oxides mineral in both terrestrial and marine settings ${ }^{9}$, play an important role in the sorption and transformation of antibiotics. ${ }^{10-13}$ Few studies have proposed birnessite coated sand as a potential geomedia in engineered infiltration systems to prevent quinolone from percolating into the groundwater sources. ${ }^{14-16}$ Although manganese oxides are of great interest from both natural and engineering points of view, most of available studies were limited to static batch experiments. ${ }^{10-13,17}$, and little is known about the assessment of redox transformation of antibiotics under flow-through conditions. Only two recent column studies have demonstrated the high reactivity of birnessite coated sand towards organic contaminants together with a progressive loss of reactivity over 
breakthrough time ${ }^{14,15}$, but mechanistic insights on the competitive adsorption of $\mathrm{Mn}^{\mathrm{II}}$ and organic

67 compounds on $\mathrm{MnO}_{2}$ surfaces and reactivity suppression under flow-through conditions is still missing. Furthermore, no data exist on how water flow variability influences the interactions of organic compounds and $\mathrm{Mn}^{\mathrm{II}}$ with birnessite surfaces. This is particularly relevant when solutes and redox byproducts (e.g. dissolved $\mathrm{Mn}^{\mathrm{II}}$ ) concurrently affect surface reactivity and thus mobility of compounds in environmental settings. Indeed, dissolved $\mathrm{Mn}^{\mathrm{II}}$ can interact with

72 hexagonal birnessite $\left(\delta-\mathrm{MnO}_{2}\right.$ and acid birnessite) and then transfer electron to lattice $\mathrm{Mn}^{\mathrm{IV}}$

73 producing $\mathrm{Mn}^{\mathrm{III}}$, which induce changes in mineral structure and composition, e.g. conversion of

74 birnessite into lower-valence Mn phases and/or modification of birnessite through adsorption or

75 incorporation of $\mathrm{Mn}^{\mathrm{III}}$ into the mineral sheets. ${ }^{18-27}$ This reductive transformation of hexagonal

76 birnessite depends on several factors, including $\mathrm{pH}$ and the ratio of dissolved $\mathrm{Mn}^{\mathrm{II}}$ to structural $77 \mathrm{Mn}^{\mathrm{IV}} \cdot 18,25$

In this study, we investigate the adsorption and redox transformation of a model quinolone antibiotic, pipemidic acid (PIP), in water saturated $\mathrm{MnO}_{2}$-coated sand columns. Acid birnessite was used as it is structurally similar (layers with hexagonal sheet symmetry comprising of edgesharing $\mathrm{Mn}^{\mathrm{IV}} \mathrm{O}_{6}$ octahedra and nanoscale particle size distribution) to biogenic birnessite found in soils. ${ }^{19,28}$ Pipemidic acid, commonly used to treat urinary tract infections in humans and animals ${ }^{29}$, was chosen as a model quinolone compound. In order to mimic natural conditions where water movement is discontinuous, we employed the 'intermittent flow/no-flow' method in the column experiments. This technique allowed also to assess changes in reactivity of manganese oxides upon modification of the residence time in column. Furthermore, we also examined the impact of two contrasting concentrations of dissolved $\mathrm{Mn}^{\mathrm{II}}$ in the reactivity of $\mathrm{MnO}_{2}$-coated sand with PIP. The dissolved $\mathrm{Mn}^{\mathrm{II}}$ concentration range was chosen in order to cover a wide variety of relevant concentration found in shallow groundwater, soil pore waters and surface waters. ${ }^{30-32}$ Finally, a 
90 transport model that accounts for oxidation and adsorption kinetics was used to help us in

91 understanding adsorption/oxidation changes of PIP in presence of dissolved $\mathrm{Mn}^{\mathrm{II}}$.

92

\section{Materials and Methods}

\subsection{Preparation and characterization of acid birnessite and manganese oxide-coated quartz}

Acid birnessite (AB) was prepared following the procedure of McKenzie (1971). More details are provided in the Supporting Information. The solid was characterized using X-ray powder diffraction (XRD) using the Bruker AXS D8 Advance diffractometer ( $\theta-2 \theta$ Bragg-Brentano geometry) using monochromatized $\mathrm{CuK \alpha} 1$ radiation. X-ray diffraction (XRD) confirmed that the only product of the synthesis was poorly-crystalline hexagonal birnessite (Fig. S1). The Mn average oxidation state (AOS) was measured to be $3.98 \pm 0.02$ (SD) using the back-titration method with $\mathrm{KMnO}_{4}$ solution. ${ }^{34}$

Scanning electron microscope (SEM; JEOL JSM-7100F) and High-resolution transmission electron microscope (HRTEM; JEOL $2100 \mathrm{LaB}_{6}$ ) were used for the ultrastructure examination of AB. SEM images showed that acid birnessite exhibits sheet stacked nanoflower spheres with a diameter of $\sim 400 \mathrm{~nm}$ (Fig. S2). HRTEM images showed aggregation of small crystalline domains surrounded by poorly-crystalline material. The surface area of AB was $57 \pm$ $4.5(\mathrm{SD}) \mathrm{m}^{2} / \mathrm{g}$ measured by $\mathrm{N}_{2}$ adsorption BET method.

The prepared birnessite was coated with Fontainebleau quartz sand $(150-200 \mu \mathrm{m})$. Prior to coating, trace metal impurities from the pure quartz were removed (see the Supporting Information for details). The clean dried quartz was then mixed with $\mathrm{AB}$ suspension (quartz to $\mathrm{AB}$ ratio of 3). The ionic strength of the suspension was adjusted to $10 \mathrm{mM}$ using $\mathrm{NaCl}$ stock solution.

The suspension was then placed in a shaker at $130 \mathrm{rpm}$ for $48 \mathrm{~h}$. The excess solution was decanted, 
112 and the solid was washed several times with $10 \mathrm{mM} \mathrm{NaCl}$ solution until the runoff was clear. Then

113 the $\mathrm{AB}$ coated quartz, hereafter referred as $\mathrm{MnO}_{2}$-coated sand (MCS), was dried at room

114 temperature. Mn content in the MCS was determined by dissolving in $30 \mathrm{mM}$ Ascorbic acid

115 following the protocol of Charbonnet et al. (2018) and analyzed with Atomic absorption 116 spectroscopy (AAS). The measured amount was $0.48 \pm 0.02$ (SD) $\mathrm{mg} \mathrm{Mn}$ in one gram of MCS.

117 The coating density was within the previously reported range. ${ }^{35}$ Scanning electron microscope /

118 Energy dispersive X-Ray spectroscopy (SEM/EDS) was applied to study the surface morphology

119 and elemental composition of the MCS. Samples were examined with a JSM JEOL $7100 \mathrm{~F}$ with a

120 field emission gun and OXFORD Genesis energy-dispersive X-ray spectrometer at $20 \mathrm{kV}$ at a

121 working distance of 5-10 $\mathrm{mm}$ and magnifications from 10,000x to 20,000x. The SEM/EDAS

122 imaging of MCS showed clusters/aggregates of $\mathrm{AB}$ inhomogenously distributed over the surface

123 of MCS (Fig. S2). Aggregates tend to accumulate in surface depressions and cracks of the quartz

124 surface. Examination using the highest SEM magnification showed particles in AB aggregates in

125 coated sand were similar in morphology as uncoated AB, suggesting no significant modification

126 in morphology occurred during the coating process. The quantitative EDAS spectra of MCS

127 showed Mn, Si, and O as the main constituents (Fig. S8). Due to extremely low Mn amount in the MCS, XRD and AOS techniques could not be used for MCS characterization.

129

\subsection{Dynamic column breakthrough experiments}

The experimental setup used for dynamic column tests is described in Zhou et al. (2019). Briefly, column experiments were conducted under ambient conditions and water-saturated conditions. Fifteen grams of MCS (containing $131 \mu \mathrm{mol} \mathrm{MnO}_{2}$ ) was packed into a glass column with an internal diameter of $1.6 \mathrm{~cm}$ and a bed length of $4.7 \mathrm{~cm}$. The uniform bulk density after packing was $\left(1.59 \pm 0.05 \mathrm{~g} / \mathrm{cm}^{3}\right)$. The pore volume $\left(\mathrm{PV}\right.$ or $\left.\mathrm{V}_{\mathrm{p}}\right)$ of the column was $4 \pm 0.1 \mathrm{~mL}$. The 
136

column was saturated with a background solution of $10 \mathrm{mM} \mathrm{NaCl}$ (previously purged with $\mathrm{N}_{2}$ ) at pH 6 with a constant flow-rate of $0.5 \mathrm{~mL} / \mathrm{min}$ (residence time of $8 \mathrm{~min}$ ). After saturation, bromide tracer experiments were performed to determine column transport properties using $10 \mathrm{mM}$ sodium bromide $(\mathrm{NaBr})$ solution at $\mathrm{pH} 6$ as input solution and ionic chromatography to determine $\mathrm{Br}^{-}$ breakthrough curve (Fig. S3). Details on calculation and interpretation of hydrodynamic parameters obtained from the bromide tracer experiments are provided in the Supporting Information. During water saturation and tracer experiments, total dissolved Mn in outflow was below the detection limit $(<0.02 \mu \mathrm{M})$, and therefore possibility of mobilization of Mn particles was excluded from the column. Blank tests conducted also confirmed no adsorption of $\mathrm{Mn}^{\mathrm{II}}$ ions to the quartz sand $\left(\leq 0.06 \mathrm{~m}^{2} / \mathrm{g}\right)$ used in this study.

Different column experiments were performed by injecting input solutions consisting of a constant amount of $10 \mathrm{mM} \mathrm{NaCl}$ and $10 \mu \mathrm{M}$ pipemidic acid but with variable concentrations of $\mathrm{Mn}^{\mathrm{II}}$. All input solutions were adjusted to $\mathrm{pH} 6 \pm 0.1$ and injected with a constant flow-rate of 0.5 $\mathrm{mL} / \mathrm{min}$, conditions close to or within range of natural soil pore water. ${ }^{37,38}$ The input solution was purged with $\mathrm{N}_{2}$ to avoid $\mathrm{CO}_{2}$ contamination and maintain the experimental $\mathrm{pH}$ throughout the course of the experiment. Flow-interruption for $24 \mathrm{~h}$ (single or double) was done in some columns to assess the effect of residence time. After complete PIP breakthrough in some columns, desorption was done by injecting $10 \mathrm{mM} \mathrm{NaCl}$ at $\mathrm{pH} 6$ at $0.5 \mathrm{~mL} / \mathrm{min}$. All effluent solutions were passed through a $0.2 \mu \mathrm{m}$ filter and were collected in $7.5 \mathrm{~mL}-15 \mathrm{~mL}$ increments using a fractional collector. The $\mathrm{pH}$ of the effluent solution was determined by using an online $\mathrm{pH}$ meter. The effluent solution was also analyzed for PIP and by-products with High performance liquid chromatography (HPLC) and Ultraperformance liquid chromatography-tandem mass spectrometry (UPLCMS/MS) system. Details on experimental set-up for these techniques are provided in the Supporting Information. Because the adsorption of target compounds is negligible at $\mathrm{pH}$ higher than 10 , 
desorption tests were conducted at $\mathrm{pH} 11$ as a means to check the mass balance. After the column experiment, the solid bed was freeze-dried. The total Mn content in MCS before and after flow experiments was determined by ascorbic acid reductive dissolution ${ }^{14}$ and AAS measurement. SEM-EDS microscopy was performed to monitor morphological changes in the reacted MCS. All experiments were conducted in duplicates and showed a good reproducibility within 5\% of average 165 standard deviation.

\subsection{Model approach}

The transport of PIP through MCS columns both in the presence and absence of $\mathrm{Mn}^{\mathrm{II}}$ was simulated using a one-dimensional advection-dispersion model coupled with a two-site nonequilibrium adsorption model. ${ }^{39}$ Hydrus-1D program was used to obtain the model parameters for

170 the two-site non-equilibrium model. The modeling approach used is explained in detail in the 171 Supporting Information.

\section{3. Results and Discussion}

\section{3.1. Adsorption and oxidation of PIP in MCS column}

176 extensive tailing when PIP was injected in pristine MCS column (Fig. 1a). The first breakthrough 177 point of PIP was at around 20 PV (pore volume) and later achieved a steady state breakthrough at 178 around $\mathrm{C} / \mathrm{C}_{0} \sim 0.95$ after injection of $600 \mathrm{PV}$. This partial breakthrough continued to be observed until the end of the column experiment (more than $1000 \mathrm{PV}$ ). Increasing the residence time in the column by interrupting flow did not influence the incomplete breakthrough, as the same partial breakthrough $\left(\mathrm{C} / \mathrm{C}_{0} \sim 0.95\right)$ was still observed upon flow resumption (Fig. 1a). This flow interruption period allowed species to react over a longer period during flow-through conditions.

183 Because the BTC of $\mathrm{Br}^{-}$used as a tracer showed no change upon flow interruption, we conclude 

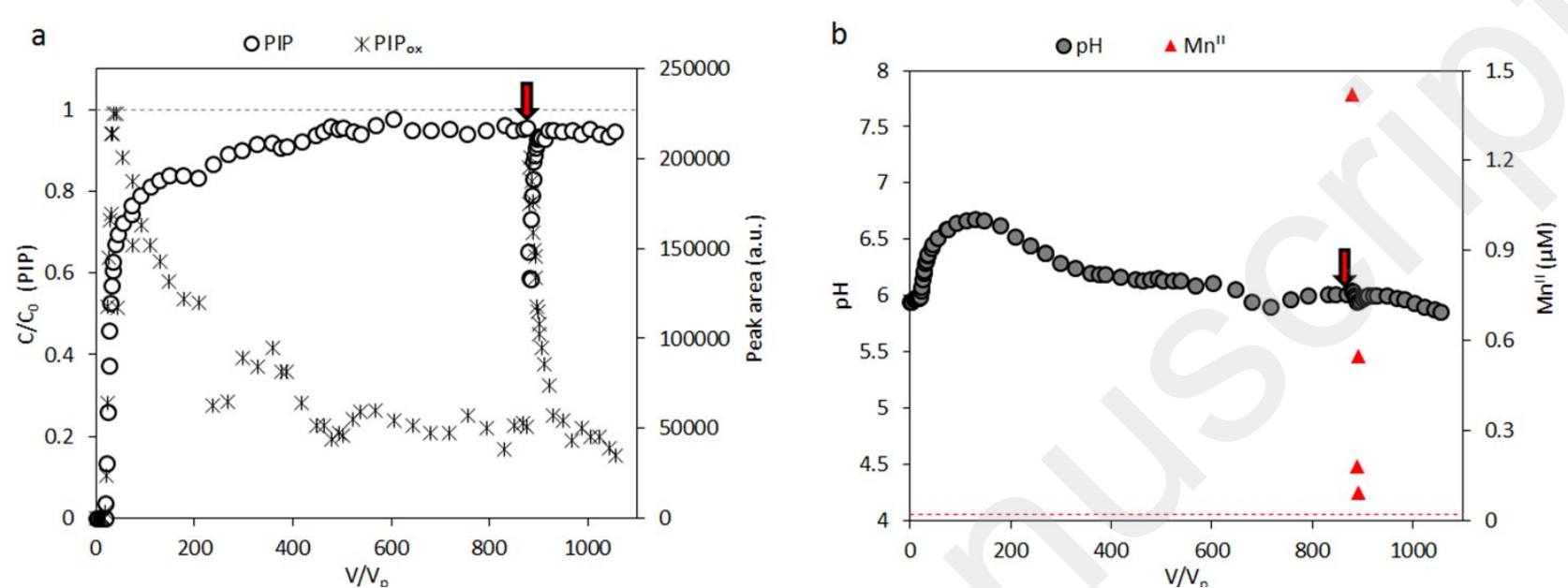

Fig. 1: Breakthrough curves of (a) PIP and PIP ${ }_{\text {ox }}$ (peak area of PIP byproduct; M-26) and (b) $\mathrm{pH}$ and $\mathrm{Mn}^{\mathrm{II}}$. The dashed lines indicate the theoretical complete breakthrough of PIP $\left(C / \mathrm{C}_{0}=1\right)$ in (a) and detection limit of $\mathrm{Mn}^{\mathrm{II}}(0.02 \mu \mathrm{M})$ in (b). The arrow indicates the moment of flow-interruption (duration $24 \mathrm{~h} ; \mathrm{V} / \mathrm{V}_{\mathrm{p}}=876$ ).

Over the course of the experiment, the $\mathrm{pH}$ of the output solution increased only slightly ( $\sim 0.6$ units), but regained the original value of the input solution ( $\mathrm{pH} 6 \pm 0.1$ ) when steady state breakthrough was attained (Fig. 1b). At our experimental $\mathrm{pH}$ range, the PIP molecule exists in a zwitterionic form $\left(\mathrm{pK}_{\mathrm{a} 1}\right.$ and $\mathrm{pK}_{\mathrm{a} 2}$ values are 5.20 and 6.38, respectively). It is previously observed that quinolones binding to negatively charged Mn-oxide surfaces possibly through a metal-bound complex may involve proton co-binding. ${ }^{13}$ This binding can be associated with a heterogeneous redox reaction where two one-electron transfer steps or a single two-electron step resulting in the concomitant oxidation of PIP and reduction of surface-bound metal. One electron is transferred from ligand to the surface-bound $\mathrm{Mn}^{\mathrm{IV}}$ to yield radical intermediate and $\mathrm{Mn}^{\mathrm{III}}$ that can be further reduced to give $\mathrm{Mn}^{\mathrm{II}}$. Subsequently, the formed radical intermediate may undergo several different reaction pathways to yield a range of by-products as shown by equation 1. A detailed step-wise reaction mechanism is provided in the Supporting Information. 


$$
\equiv \mathrm{Mn}^{\mathrm{IV}}+\mathrm{PIP} \rightarrow \equiv \mathrm{Mn}^{\mathrm{IV}}-\mathrm{PIP}_{\mathrm{ad}} \rightarrow \equiv \mathrm{Mn}^{\mathrm{III}} / \mathrm{Mn}^{\mathrm{II}}-\mathrm{PIP}^{+} \rightarrow \mathrm{Mn}^{\mathrm{II}}+\mathrm{PIP}_{\mathrm{ox}}
$$
performed using $0.25 \mathrm{~g}$ MCS $\left(2.2 \mu \mathrm{mol} \mathrm{MnO}_{2}\right)$ reacted with $10 \mu \mathrm{M}$ PIP and $10 \mathrm{mM} \mathrm{NaCl}$ solution occur (Fig. 2). As an initial kinetic stage, the adsorbed amount increased to reach a maximum and then decreased. Once the PIP adsorbed reached a sufficient amount to trigger oxidation reaction,

214 aqueous concentration was below the detection limit $(0.02 \mu \mathrm{M})$, most likely due to strong binding 215 of $\mathrm{Mn}^{\mathrm{II}}$ to MCS surfaces at the working $\mathrm{pH}$ (i.e. $\mathrm{pH}$ 6). Indeed, adsorption isotherm determined at $216 \mathrm{pH} 6$ showed great affinity of $\mathrm{Mn}^{\mathrm{II}}$ to $\mathrm{MCS}$ at the first stage, followed by an almost linear increase 217 of adsorbed amount with increasing equilibrated $\mathrm{Mn}^{\mathrm{II}}$ concentration (Fig. S4). Since our 218 experiments were performed under air ambient conditions, surface-catalyzed oxidation of $\mathrm{Mn}^{\mathrm{II}}$ by 219 molecular oxygen could enable more $\mathrm{Mn}^{\mathrm{II}}$ sorption under oxic conditions relative to anoxic systems 220 through the formation of new phases such as feitknechtite and/or manganite, as previously 221 reported. ${ }^{18}$ However, it was also reported that formation of these lower valence Mn phases prevails 222 at $\mathrm{pH}$ values higher than the working $\mathrm{pH}$ here $(\mathrm{pH}>7)$ and for high ratio of dissolved $223 \mathrm{Mn}^{\mathrm{II}} / \mathrm{MnO}_{2} \cdot{ }^{18,25}$ Only a disturbance of stacking of $\mathrm{MnO}_{2}$ sheets with no mineralogical 224 transformation has been observed at $\mathrm{pH} 6 .{ }^{18} \mathrm{We}$ verified this by conducting $\mathrm{Mn}^{\mathrm{II}}$ isotherm 225 experiments with uncoated acid birnessite at $\mathrm{pH} 6( \pm 0.1)$ under both oxic and anoxic conditions. 226 Both isotherms overlapped at low range of $\mathrm{Mn}^{\mathrm{II}} / \mathrm{MnO}_{2}$ ratio, indicating no influence of $\mathrm{O}_{2}$ at the experimental conditions of column tests. Only at higher $\mathrm{Mn}^{\mathrm{II}} / \mathrm{MnO}_{2}$ ratio $(\geq 1.38)$, sharp removal in 

the results of all isotherm experiments is provided in the Supporting Information.

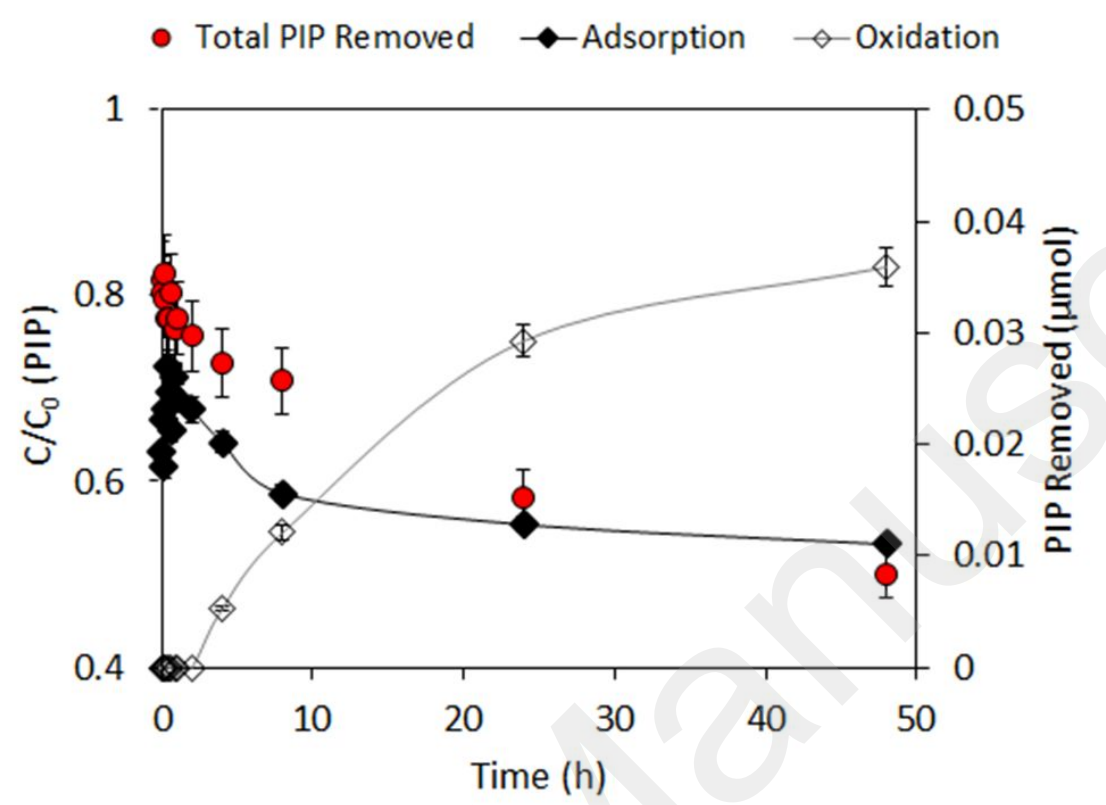

The incomplete PIP breakthrough observed here (Fig.1) suggests that both adsorption and transformation of PIP may also occur in the column system. The drop in PIP concentration under no-flow condition can result from rate-limited sorption/redox processes. Redox byproducts were then monitored in column effluent throughout the whole breakthrough time. Dissolved $\mathrm{Mn}^{\mathrm{II}}$ concentration was below the AAS detection limit $(<0.02 \mu \mathrm{M})$, most likely because of the high tendency of manganese ions to be adsorbed at the oxide surface at the working $\mathrm{pH}$. Dissolved $\mathrm{Mn}^{\mathrm{II}}$ (up to $1.5 \mu \mathrm{M}$ ) was only detected in column effluent after $24 \mathrm{~h}$ flow interruption and then flow resumption (Fig. 1b), probably because of generation of higher amount of $\mathrm{Mn}^{\mathrm{II}}$. Indeed, flow interruption provided additional time for the PIP oxidation reaction to occur (eq. 1), resulting in 
248 accumulation of $\mathrm{Mn}^{\mathrm{II}}$ as redox byproduct in the column. Sorption of $\mathrm{Mn}^{\mathrm{II}}$ to $\mathrm{MnO}_{2}$ surfaces may 249 continue to proceed during the flow-interruption period, but was not able to entirely remove all 250 accumulated $\mathrm{Mn}^{\mathrm{II}}$. When flow was recommenced, elution of the interrupt-period resident solution 251 caused a decrease in PIP concentration and an increase in $\mathrm{Mn}^{\mathrm{II}}$ concentration (Fig. 1b). Continuous 252 injection of inflow solution led to an increase of PIP aqueous concentration up to reach the initial 253 value and a decrease of $\mathrm{Mn}^{\mathrm{II}}$ concentration below the detection limit.

254

255

256

257

258

259

260

261

262

263

264

In order to assess the PIP oxidation reaction, all possible byproducts previously detected for analogous quinolone compounds ${ }^{13,42}$ were searched by LC/MS. Consistently with past observations, PIP can be oxidized by $\mathrm{MnO}_{2}$ through two one-electron transfers from the $\mathrm{N}$ atom of piperazine ring to $\mathrm{Mn}^{\mathrm{IV}}$, generating $\mathrm{Mn}^{\mathrm{II}}$ and PIP cation radical. Further changes on the PIP cation radical can happen through $\mathrm{C}$-hydroxylation and/or N-dealkylation that cause ring opening and subsequently forming several byproducts, as typically observed for other quinolones. ${ }^{11,13}$ However, only one predominant species of mass-to-charge ratio of $\mathrm{m} / \mathrm{z}=227$ can be detected using LC/MS (Fig. S6). The peak area of the LC/MS data of this species corresponding to M-26 (hereafter called $\mathrm{PIP}_{\mathrm{ox}}$ ) followed PIP breakthrough to reach a steady state (Fig. 1a). Because standards are not commercially available, an accurate quantification of formed species cannot be performed.

$\mathrm{PIP}_{\text {ox }}$ broke out at the same time as the mother compound, reached a maximum and then decreased after $\sim 100 \mathrm{PV}$ to have a plateau (Fig. 1a). When the flow is resumed after $24 \mathrm{~h}$ flow interruption period, $\mathrm{PIP}_{\mathrm{ox}}$ concentration spiked up before reaching plateau again, suggesting the occurrence of kinetically limited redox process in the column system. Both sorption/desorption and oxidation reactions are expected during the flow interruption event, PIP concentration decreased and byproduct concentration increased, and then approached constant steady-state values. Because of a constant partial breakthrough (i.e. $\mathrm{C} / \mathrm{C}_{0}<1$ ) observed, ongoing oxidation and formation of 
272 primary byproduct is highly expected. This primary byproduct reached a steady state concentration, 273 thereby suggesting that a sorption/desorption equilibrium was reached.

The generation of redox byproducts (e.g. $\mathrm{Mn}^{\mathrm{II}}$ ) which in turn interact with $\mathrm{MnO}_{2}$ surfaces may influence the ongoing oxidation reaction in the column, and thus affect the transport behavior of PIP in the column system. Furthermore, redox byproducts are flushing out of the column or moving up toward further zones, while they remained in contact with the reacted solid under static batch conditions. In order to test this hypothesis, the impact of dissolved $\mathrm{Mn}^{\mathrm{II}}$ on the $\mathrm{MnO}_{2}$

reactivity was investigated under two situations: (i) PIP injection in $\mathrm{Mn}^{\mathrm{II}}$-preloaded column and

(ii) simultaneous injection of PIP and dissolved $\mathrm{Mn}^{\mathrm{II}}$ in pristine columns.

\subsection{Effects of dissolved $\mathrm{Mn}^{\mathrm{II}}$ on the $\mathrm{MnO}_{2}$ reactivity and PIP oxidation in column}

In the $\mathrm{Mn}^{\mathrm{II}}$-preloaded column experiment, $\mathrm{Mn}^{\mathrm{II}}$ and PIP were injected in column after injection of $\sim 346 \mathrm{PV}$ with $\mathrm{Mn}^{\mathrm{II}}$ solution $(10 \mu \mathrm{M})$, i.e. $\sim 14 \mu \mathrm{mol}$ of $\mathrm{Mn}^{\mathrm{II}}$ was reacted with $7.2 \mathrm{mg}$ and breakthrough curve shape, as compared to no-preloading experiment (Fig. 3a and 1a). The BTC of PIP became more sigmoidal/steeper, with an early breakthrough occurring at $\sim 10 \mathrm{PV}$ and then a complete breakthrough at $\sim 60 \mathrm{PV}$. No extensive tailing in both adsorption and desorption fronts (curve symmetry) was observed here relative to the BTC of PIP in no-preloading column.

290 Furthermore, complete breakthrough (i.e. $\mathrm{C} / \mathrm{C}_{0}=1$ ) of PIP was achieved, suggesting very low to negligible oxidation extent under these experimental conditions. This was confirmed by the very low amount of $\mathrm{PIP}_{\text {ox }}$ detected in the column effluent (Fig. 3b). Since the oxidation was almost absent, the total removed amount of PIP in column should correspond to the adsorbed amount, 294 determined as $\sim 0.65 \mu \mathrm{mol}$ of PIP bound to $\mathrm{Mn}^{\mathrm{II}}$ preloaded MCS by integrating the breakthrough 
curve. This amount was considerably lower than that of the total PIP removed (adsorbed + 296 oxidized $)$ in no-preloading column $(\sim 2.6 \mu \mathrm{mol})$.

The complete PIP breakthrough and an incomplete $\mathrm{Mn}^{\mathrm{II}}$ breakthrough suggested preferential adsorption of $\mathrm{Mn}^{\mathrm{II}}$ over PIP in the $\mathrm{Mn}^{\mathrm{II}}$ preloaded MCS (Fig. 3). A total of $\sim 22 \mu \mathrm{mol}$ of $\mathrm{Mn}^{\mathrm{II}}$ was injected over the whole course of experiment, but only $8.2 \mu \mathrm{mol}$ of total $\mathrm{Mn}^{\mathrm{II}}$ was 300 removed (adsorbed + oxidized) as calculated by integrating breakthrough curve. This low $301 \mathrm{Mn}{ }^{\mathrm{II}} / \mathrm{MnO}_{2}$ ratio (0.17) may explain why complete breakthrough of $\mathrm{Mn}^{\mathrm{II}}$ was never attained in the 302 MCS column.

During $\mathrm{Mn}^{\mathrm{II}}$ preloading the solution $\mathrm{pH}$ rapidly decreased by $\sim 1.5$ units, most likely 304 because of release of $\mathrm{H}^{+}$in the solution upon binding of $\mathrm{Mn}^{\mathrm{II}}$ ions to $\mathrm{MnO}_{2}$ surfaces. Afterwards, 305 outflow pH gradually increased to regain the inflow value, even after simultaneous injection of $306 \mathrm{Mn}^{\mathrm{II}}$ and PIP. Desorption front suggests that not all $\mathrm{Mn}^{\mathrm{II}}$ previously removed was released during 307 desorption with $10 \mathrm{mM} \mathrm{NaCl}$. Previous work indicates that monovalent cations like $\mathrm{Na}^{+}$cannot completely displace $\mathrm{Mn}^{\mathrm{II}}$ from the $\mathrm{MnO}_{2}$ structures. ${ }^{43}$ Additional desorption tests in batch using 25 $\mathrm{mM}$ of $\mathrm{Ca}^{\mathrm{II}}$ as a desorption agent of solid-bound $\mathrm{Mn}^{\mathrm{II}} 16$ did not allow more than $10 \%$ of previously adsorbed $\mathrm{Mn}^{\mathrm{II}}$. We cannot rule out the possibility that comproportionation of $\mathrm{Mn}^{\mathrm{II}}$ to $\mathrm{Mn}^{\mathrm{III}}$ might 311 have occurred under our experimental conditions, even if adsorption of $\mathrm{Ca}^{\mathrm{II}}$ on vacant sites is much 312 weaker than $\mathrm{Mn}^{\mathrm{II}}$ and only high $\mathrm{pH}$ favors comproportionation reaction forming $\mathrm{Mn}^{\mathrm{III}} .{ }^{44}$ Indeed, 313 infrared spectroscopic investigations (Fig. S5b) for uncoated $\mathrm{MnO}_{2}$ in batch confirmed that 314 transformation of hexagonal birnessite to manganite $\left(\gamma-\mathrm{Mn}^{\mathrm{III}} \mathrm{OOH}\right)$ only occurred at high $\mathrm{pH}$ (i.e. 315 8) and high ratio of $\mathrm{Mn}^{\mathrm{II}}$ to $\mathrm{MnO}_{2}(2.3)$. 

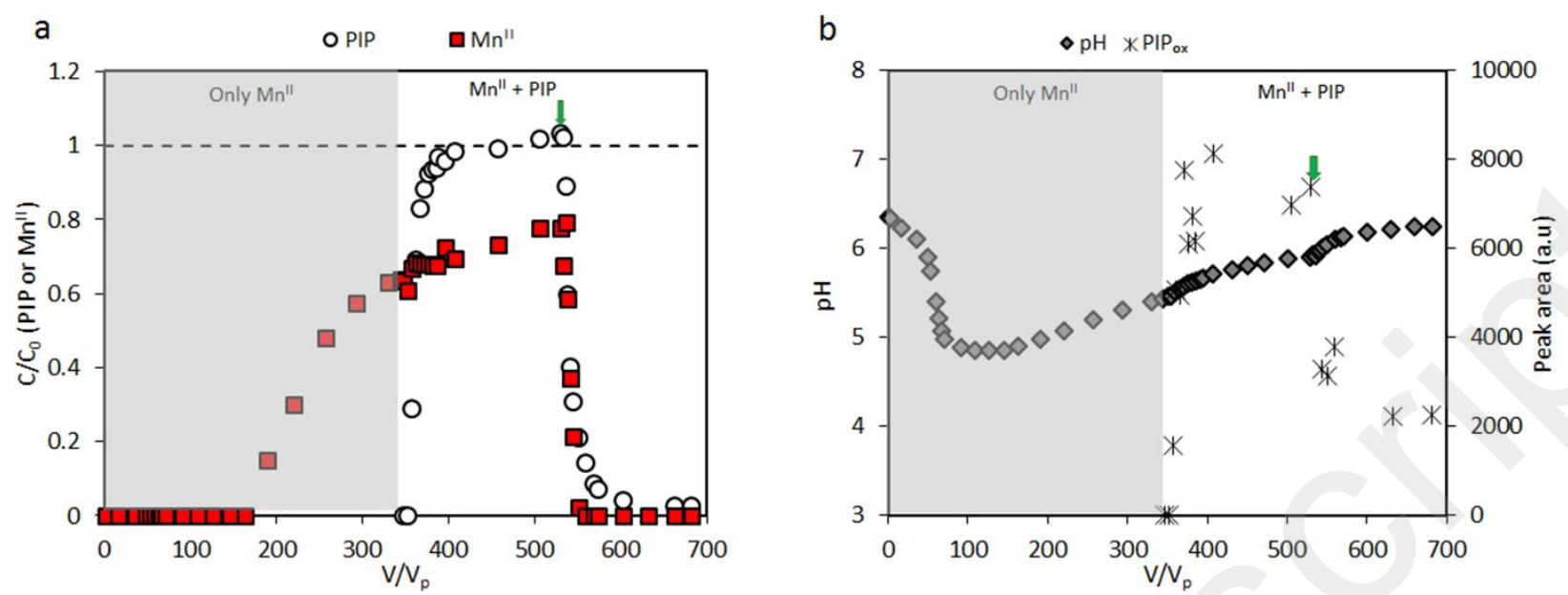

Fig. 3: Breakthrough curves of (a) PIP and $\mathrm{Mn}^{\mathrm{II}}$ and (b) $\mathrm{pH}$ and PIP ${ }_{\mathrm{ox}}$ (peak area of PIP byproduct; M-26). The gray area represent $\mathrm{Mn}^{\mathrm{II}}$ preloading period where an input solution consisting of $10 \mu \mathrm{M} \mathrm{Mn}{ }^{\mathrm{II}}$ and 10 $\mathrm{mM} \mathrm{NaCl}$ was injected (up to $344 \mathrm{~V} / \mathrm{V}_{\mathrm{p}}$ ), and the white area represent injection of $10 \mu \mathrm{M} \mathrm{Mn} \mathrm{MI}^{\mathrm{II}} 10 \mu \mathrm{M}$ PIP and $10 \mathrm{mM} \mathrm{NaCl}$. The dashed lines indicate the theoretical complete breakthrough of PIP $\left(\mathrm{C} / \mathrm{C}_{0}=1\right)$. The arrow indicates point of injection of $10 \mathrm{mM} \mathrm{NaCl}$ solution for desorption $\left(\mathrm{V} / \mathrm{V}_{\mathrm{p}}=530\right)$. Inflow conditions: $10 \mu \mathrm{M}$ PIP, pH: $6.2 \pm 0.1,10 \mathrm{mM} \mathrm{NaCl}, \mathrm{PV}: 4 \mathrm{~mL}$, flowrate: $0.5 \mathrm{~mL} / \mathrm{min}$.

Simultaneous injection of $\mathrm{Mn}^{\mathrm{II}}$ and PIP in pristine MCS column altered PIP mobility relative to injection of PIP alone in pristine MCS column or in $\mathrm{Mn}^{\mathrm{II}}$-preloaded column. When low amount of $\mathrm{Mn}^{\mathrm{II}}(10 \mu \mathrm{M})$ was used, higher amount of $\mathrm{PIP}_{\text {ox }}$ was detected in the column effluent resulting in a partial breakthrough of PIP (Fig. 4a). Complete breakthrough of PIP was only achieved after two interruption events through generation of more redox byproducts and thus by complete passivation of $\mathrm{MnO}_{2}$ (Fig. 4a). At each flow interruption event, PIP concentration decreased and $\mathrm{PIP}_{\mathrm{ox}}$ and $\mathrm{Mn}^{\mathrm{II}}$ concentration increased, and then approached constant steady-state value (Fig. 4a and 4b). The $\mathrm{PIP}_{\text {ox }}$ became negligible after the second interruption event, as complete breakthrough was achieved for PIP.

Higher $\mathrm{Mn}^{\mathrm{II}}$ loading $(117 \mu \mathrm{M})$ led to a steeper BTC and earlier breakthrough as compared to the BTC of PIP injected alone or with $10 \mu \mathrm{M}$ of $\mathrm{Mn}^{\mathrm{II}}$ (Fig. 4a, 4c, and 1a). The sharp decrease in $\mathrm{pH}$ during $\mathrm{Mn}^{\mathrm{II}}$ adsorption followed by a gradual increase to regain the original input value was observed here for both $\mathrm{Mn}^{\mathrm{II}}$ doses (Fig. $4 \mathrm{~b}$ and $4 \mathrm{~d}$ ). However, the decrease in $\mathrm{pH}$ was more 
339 pronounced during the high $\mathrm{Mn}^{\mathrm{II}}$ dose, indicating more $\mathrm{Mn}^{\mathrm{II}}$ adsorption. As expected, reacted $\mathrm{Mn}^{\mathrm{II}}$ 340 amount $(\sim 6.4 \mu \mathrm{mol})$ estimated at the breakthrough point of PIP was higher than in the low $\mathrm{Mn}^{\mathrm{II}}$ 341 dose column $(\sim 0.7 \mu \mathrm{mol})$. Furthermore, a complete PIP breakthrough was attained in the high $\mathrm{Mn}^{\mathrm{II}}$ 342 dose and very low amount of PIP $_{\text {ox }}$ detected in column effluent, suggesting very low to negligible 343 oxidation rate in this column. The desorption front of both PIP and $\mathrm{Mn}^{\mathrm{II}}$ indicated no significant 344 tailing and an incomplete $\mathrm{Mn}^{\mathrm{II}}$ removal, similar to that observed in the $\mathrm{Mn}^{\mathrm{II}}$ preloaded column. estimated before PIP breakthrough point $(0.7 \mu \mathrm{mol})$ was much lower than $8.2 \mu$ mol removed in the $347 \mathrm{Mn}^{\mathrm{II}}$ preloaded column over the whole course of the experiment. This may explain why complete 348 suppression of $\mathrm{MnO}_{2}$ oxidative ability was only observed in the $\mathrm{Mn}^{\mathrm{II}}$ preloaded column. However, injection of higher amount of $\mathrm{Mn}^{\mathrm{II}}$ together with PIP, led to higher amount of removed $\mathrm{Mn}^{\mathrm{II}}(6.3$ $\mu \mathrm{mol}$ ), and thus complete suppression of $\mathrm{MnO}_{2}$ oxidative ability. This falls in line with the very 351 low amount of $\mathrm{PIP}_{\mathrm{ox}}$ observed in both high $\mathrm{Mn}^{\mathrm{II}}$ dose and $\mathrm{Mn}^{\mathrm{II}}$ preloading experiments.

A complete breakthrough of $\mathrm{Mn}^{\mathrm{II}}$ was also achieved after the second flow interruption 353 (Fig. 4b). The $\mathrm{C} / \mathrm{C}_{0}$ of $\mathrm{Mn}^{\mathrm{II}}$ greater than 1 indicates the generation of dissolved $\mathrm{Mn}^{\mathrm{II}}$ from reductive 354 dissolution of $\mathrm{MnO}_{2}$. This reductive dissolution has been confirmed by measuring the total Mn 355 amount in the reacted MCS column. Around 44\% decrease in total Mn content was observed as 356 compared to the unreacted MCS. For other column experiments, only $15 \%$ decrease in total Mn 357 content was measured in the reacted MCS after breakthrough experiment. Taken together, the 358 results showed that injection of high amount of $\mathrm{Mn}^{\mathrm{II}}$ or in situ generation of dissolved $\mathrm{Mn}^{\mathrm{II}}$, for instance through flow interruption, may suppress PIP oxidation in the MCS columns. 

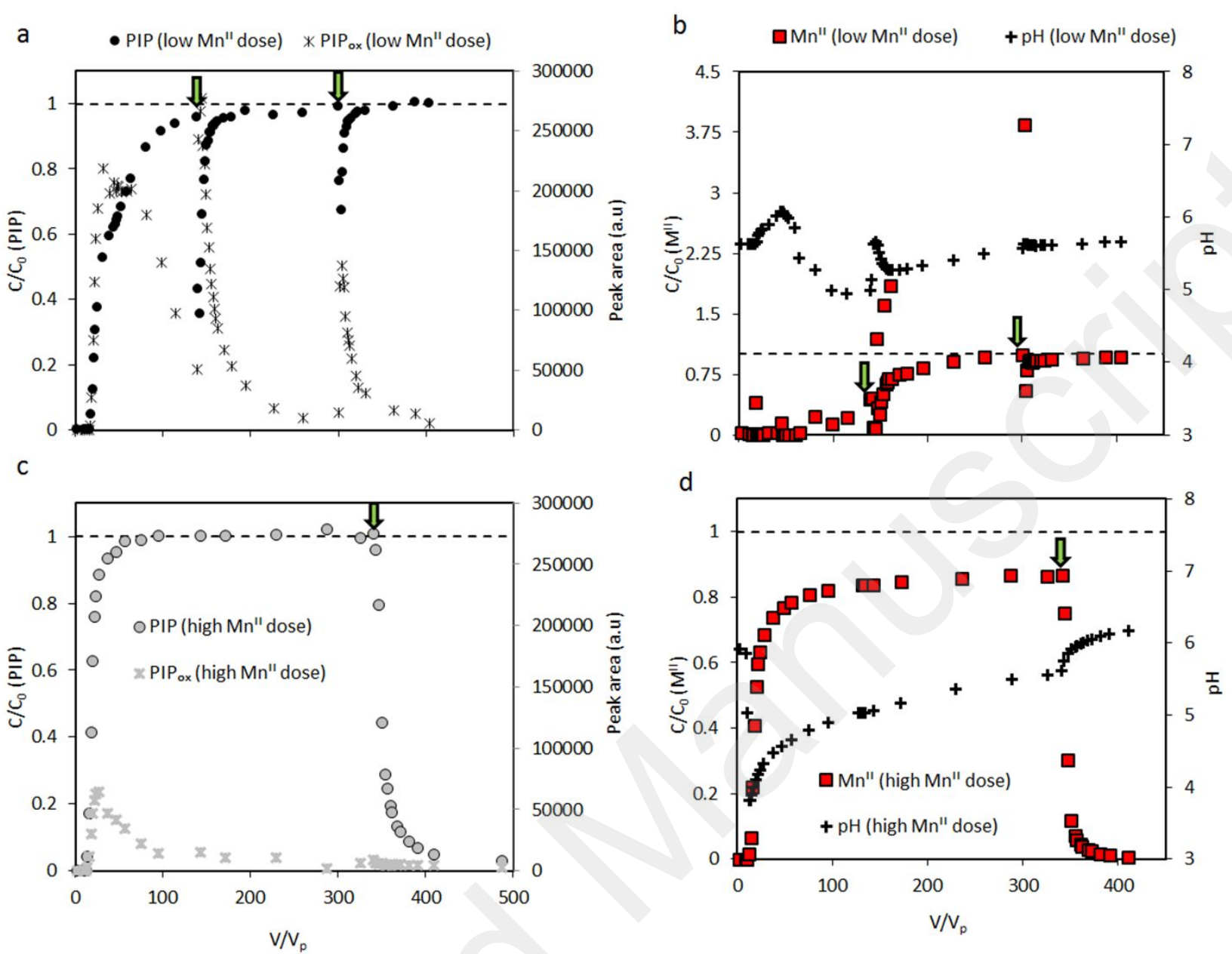

Fig. 4: Breakthrough curves of (a) PIP and PIP ${ }_{\text {ox }}$ (peak area of PIP byproduct; M-26) and (b) $\mathrm{pH}$ and $\mathrm{Mn}^{\mathrm{II}}$ for experiment with low $\mathrm{Mn}^{\mathrm{II}}$ loading $(10 \mu \mathrm{M})$. Breakthrough curves of (c) PIP and PIP ox (peak area of PIP byproduct; M-26) and (d) $\mathrm{pH}$ and $\mathrm{Mn}^{\mathrm{II}}$ for experiment with high $\mathrm{Mn}^{\mathrm{II}}$ loading $(117 \mu \mathrm{M})$. All dashed lines indicate the theoretical complete breakthrough of PIP or $\mathrm{Mn}^{\mathrm{II}}\left(\mathrm{C} / \mathrm{C}_{0}=1\right)$. Arrows in (a) and (b) indicate the moment of flow-interruption (duration $24 \mathrm{~h}$ each; $\mathrm{V} / \mathrm{V}_{\mathrm{p}}=139$ and 300), whereas arrows in (c) and (d) indicates point of injection of $10 \mathrm{mM} \mathrm{NaCl}$ solution for desorption $\left(\mathrm{V} / \mathrm{V}_{\mathrm{p}}=341\right)$. Inflow conditions: low $\mathrm{Mn}^{\mathrm{II}}$ column: $10 \mu \mathrm{M} \mathrm{Mn}{ }^{\mathrm{II}}, 10 \mu \mathrm{M}$ PIP, pH: $5.8 \pm 0.1,10 \mathrm{mM} \mathrm{NaCl}, \mathrm{PV}: 4 \mathrm{~mL}$, flowrate: $0.5 \mathrm{~mL} / \mathrm{min}$; high $\mathrm{Mn}^{\mathrm{II}}$ column: $117 \mu \mathrm{M}$; $10 \mu \mathrm{M}$ PIP, pH: $6.1 \pm 0.1,10 \mathrm{mM} \mathrm{NaCl}$, PV: $4 \mathrm{~mL}$, flowrate: $0.5 \mathrm{~mL} / \mathrm{min}$.

\subsection{PIP oxidation mechanisms in $\mathrm{Mn}^{\mathrm{II}} / \mathrm{MnO}_{2}$ systems}

The structure of acid birnessite consists of two adsorption sites within its $\mathrm{Mn}^{\mathrm{IV}} \mathrm{O}_{6}$ octahedra layers: 1) edge sites at the edge of $\mathrm{Mn}^{\mathrm{IV}}$ octahedral sheets and 2) vacancy sites within the $\mathrm{Mn}^{\mathrm{IV}}$ octahedral sheets. ${ }^{45}$ Because of their high density of negative charge, vacancies sites could be the primary location for cationic species (e.g. heavy metals), while high electronegative 
375 species (e.g. anionic species) would prefer edges sites. ${ }^{46}$ As observed for oxyanions (e.g. As ${ }^{\mathrm{III}}$ and

$\left.376 \mathrm{As}^{\mathrm{V}}\right)^{47-49}$ or anionic ligands (e.g. phosphate) $)^{46,50}$, it is likely that organic ligands such as pipemidic

377 acid can be probably sorbed at edge sites. On the other hand, numerous studies reported that binding

378 of cationic metals (e.g. $\mathrm{Ni}^{\mathrm{II}}, \mathrm{Zn}^{\mathrm{II}}, \mathrm{Mn}^{\mathrm{II}}$ ) likely occurs on edge sites as well as vacancy sites of

379 hexagonal birnessite. ${ }^{51,52}$ For example, some reports showed that $\mathrm{Mn}^{\mathrm{II}}$ is preferentially sorbed at

380 vacancy sites (higher thermodynamic stability forming triple corner-sharing complexes by sharing

381 corners of its octahedral shell with $\mathrm{Mn}^{\mathrm{IV}}$ octahedral corners) until they are all occupied, and when

382 all vacancy sites are occupied, $\mathrm{Mn}^{\mathrm{II}}$ will bind for the edge sites. ${ }^{47,49,53}$ However, a recent work

383 reported that binding mechanisms of some cations (e.g. $\left.\mathrm{Co}^{\mathrm{II}}\right)$ are time dependent, i.e. they react

384 first with edge sites within the first $10 \mathrm{~min}$, and then diffuse to the vacancy sites at longer reaction

385 times. ${ }^{54,55}$ Collectively, we can assume that vacancies sites are the long-term adsorption and

386 oxidation sites for cationic metals (e.g. $\mathrm{Mn}^{\mathrm{II}}$ ), whereas edges sites tend to interact with anionic

387 species (e.g. PIP). At the first kinetic phase, competition between PIP and $\mathrm{Mn}^{\mathrm{II}}$ to edges sites can

388 be expected.

When PIP is injected in pristine MCS column, PIP molecule will preferentially bind at the 390 edge sites of $\mathrm{MnO}_{2}$, followed by electron-transfer reactions from ligand to surface-bound $\mathrm{Mn}^{\mathrm{IV}}$ resulting in the concomitant generation of $\mathrm{PIP}_{\text {ox }}$ and $\mathrm{Mn}^{\mathrm{II}}$, which can in turn interact with $\mathrm{MnO}_{2}$

392 surfaces. The suppression of the oxidative ability of $\mathrm{MnO}_{2}$ or the decrease in oxidation rate 393 observed in the PIP/ $\mathrm{MnO}_{2}$ system under both batch and flow-through conditions, may result from 394 competition of PIP and $\mathrm{Mn}^{\mathrm{II}}$ to interact with reactive surface sites and/or aqueous complexation of 395 PIP with $\mathrm{Mn}^{\mathrm{II}}$. The latter can be easily excluded because of weaker aqueous complexation of quinolones with divalent cations such as $\mathrm{Mn}^{\mathrm{II}} .{ }^{56}$ However, more favorable electrostatic interactions

397 exist between cationic metals and the negatively charged $\mathrm{MnO}_{2}$ surface, thereby suggesting competition of PIP and $\mathrm{Mn}^{\mathrm{II}}$ for surface sites. Furthermore, the generated $\mathrm{Mn}^{\mathrm{II}}$ can exchange 
399 electrons with $\mathrm{Mn}^{\mathrm{IV}}$ to form two $\mathrm{Mn}^{\mathrm{III}}$ centers and, conversely, two $\mathrm{Mn}^{\mathrm{III}}$ centers can 400 disproportionate to form $\mathrm{Mn}^{\mathrm{II}}$ and $\mathrm{Mn}^{\mathrm{IV}}$ centers. ${ }^{16}$

401 When $\mathrm{Mn}^{\mathrm{II}}$ is first injected in MCS column (i.e. preloading experiment), $\mathrm{Mn}^{\mathrm{II}}$ will interact 402 first with edge sites and later diffuse to the vacancy sites (if we assume a similar behavior like $403 \mathrm{Co}^{\mathrm{II}}$ ). The vacancy content ranges from 6\% (lowest) to $20 \%$ (highest) of total Mn content (131 $404 \mu \mathrm{mol}$ here), corresponds to 8 and $26 \mu \mathrm{mol}$ of vacancies, respectively. ${ }^{28,57}$ In $\mathrm{Mn}^{\mathrm{II}}$ preloading, 14 $405 \mu \mathrm{mol}$ of $\mathrm{Mn}^{\mathrm{II}}$ was reacted before PIP injection, being within the range of the estimated vacancy 406 content. If the diffusion-limited transport to vacancy sites makes the edges sites free again 407 (potential binding sites for PIP), no competition between PIP and $\mathrm{Mn}^{\mathrm{II}}$ is expected here. However, 408 the total adsorbed amount of PIP $(\sim 0.65 \mu \mathrm{mol})$ was much lower in the preloaded column than in 409 other columns (e.g. pristine column). This observation can be explained if $\mathrm{Mn}^{\mathrm{II}}$ still occupied edges 410 sites and compete with PIP, which could also depend on the amount of dissolved $\mathrm{Mn}^{\mathrm{II}}$. Indeed, 411 previous spectroscopic investigations of $\mathrm{Co}$ binding at hexagonal birnessite $\left(\delta-\mathrm{MnO}_{2}\right)$ surfaces 412 suggested that at longer time scale $(\mathrm{t}>10 \mathrm{~min})$ the adsorbed amount at vacancy sites keep 413 increasing, while the amount at particle edges remained constant or decreased depending on the 414 absence or presence of aqueous $\mathrm{Co}^{\mathrm{II}} .{ }^{55}$ Unlike static batch reactors where the aqueous concentration 415 of species tend to deplete, continuous supply of $\mathrm{Mn}^{\mathrm{II}}$ into MCS column enabled more competition 416 for both edge and vacancy sites. This observation was supported by our batch data (Fig. S7 and 2) 417 where adsorption of PIP remained constant with or without adding $\mathrm{Mn}^{\mathrm{II}}$ at longer reaction times 418 i.e. $24 \mathrm{~h}$, but lower oxidation rate was observed in presence of dissolved $\mathrm{Mn}^{\mathrm{II}}$. Since all $\mathrm{Mn}^{\mathrm{II}}$ was 419 removed within the first 10 minutes in batch, PIP may compete with $\mathrm{Mn}^{\mathrm{II}}$ as a first step (Fig. S7). 420 When diffusion of $\mathrm{Mn}^{\mathrm{II}}$ to vacancy sites take place, edge sites became free because of depleted 421 aqueous $\mathrm{Mn}^{\mathrm{II}}$ in batch and thus competition became less pronounced. 
When PIP and $\mathrm{Mn}^{\mathrm{II}}$ are simultaneously injected, PIP and $\mathrm{Mn}^{\mathrm{II}}$ will compete to bind at the

423 edge sites as a first kinetic stage. Later when the edge sites are filled, $\mathrm{Mn}^{\mathrm{II}}$ will diffuse to the

424 vacancy sites. Since most of PIP adsorption takes place in the first injected PV, there is probably

425 competition between PIP and $\mathrm{Mn}^{\mathrm{II}}$ to bind at the edge sites, particularly for a short residence time

426 in the column (i.e. $8 \mathrm{~min}$ ). The amount of PIP removed was higher than in the preloading

427 experiment where edges sites were mostly pre-occupied by $\mathrm{Mn}^{\mathrm{II}}$. On the other hand, the amount of

428 PIP removed (adsorbed + oxidized) determined by integrating the BTC decreased with increasing

429 in $\mathrm{Mn}^{\mathrm{II}}$ dose $\left(1.65 \mu \mathrm{mol}\right.$ at $10 \mu \mathrm{M}$ of $\mathrm{Mn}^{\mathrm{II}}$ vs $0.78 \mu \mathrm{mol}$ for $117 \mu \mathrm{M}$ of $\left.\mathrm{Mn}^{\mathrm{II}}\right)$. When $\mathrm{Mn}^{\mathrm{II}}$ is in situ

430 generated through flow interruption events, the binding and oxidative abilities of $\mathrm{MnO}_{2}$ are further

431 suppressed. Since high amount of $\mathrm{Mn}^{\mathrm{II}}$ is required to completely passivate MCS, several flow-

432 interruptions events are needed to achieve complete breakthrough of PIP. This is also the case when

433 low amount of $\mathrm{Mn}^{\mathrm{II}}$ was used (Fig 4a).

As mentioned previously, the incomplete desorption of adsorbed $\mathrm{Mn}^{\mathrm{II}}$ in column could 435 also suggest the formation of $\mathrm{Mn}^{\mathrm{III}}$ species through comproportionation reaction of bound $\mathrm{Mn}^{\mathrm{II}}$ 436 with structural $\mathrm{Mn}^{\mathrm{IV}}$. However, no further adsorption of PIP is observed throughout all 437 breakthrough experiment (i.e. $\mathrm{C} / \mathrm{C}_{0}$ remained constant), unlike $\mathrm{As}{ }^{\mathrm{III}}$ and $\mathrm{As}{ }^{\mathrm{V}}$ binding to newly 438 formed $\mathrm{Mn}^{\mathrm{III}}$ species previously reported. ${ }^{47,49}$ Additionally, both ATR-FTIR and SEM/EDAS 439 results showed no substantial differences in terms of composition or morphology between 440 unreacted and reacted solids (Fig. S8), further ruling out significant mineral transformation under 441 our experimental conditions.

443 using a two-site non-equilibrium model in order to describe the breakthrough curves of PIP in no444 preloaded and preloaded columns. Lower values for adsorption and oxidation parameters $\left(R_{f}\right.$ or $K_{d}$ 
445 and $\mu_{s}$ respectively; Table S1; Fig. 5) are required to accurately fit the experimental BTC in 446 presence of $\mathrm{Mn}^{\mathrm{II}}$. In simultaneous injection experiments, high dose of $\mathrm{Mn}^{\mathrm{II}}$ led to lower adsorption 447 extent $\left(K_{d}\right.$ or $\left.R_{f}\right)$, as expected from the experimental BTC. It is worth noting that fitted values of $448 K_{d}$ and $\mu_{s}$ in $\mathrm{Mn}^{\mathrm{II}}$ preloaded and high $\mathrm{Mn}^{\mathrm{II}}$ dose column are close, confirming extensive suppression 449 of $\mathrm{MnO}_{2}$ reactivity in these columns. Indeed, complete breakthrough of PIP was observed upon 450 adsorption of high amount of $\mathrm{Mn}^{\mathrm{II}}$ in MCS through preloading or injection of higher amount of 451 dissolved $\mathrm{Mn}^{\mathrm{II}}$.

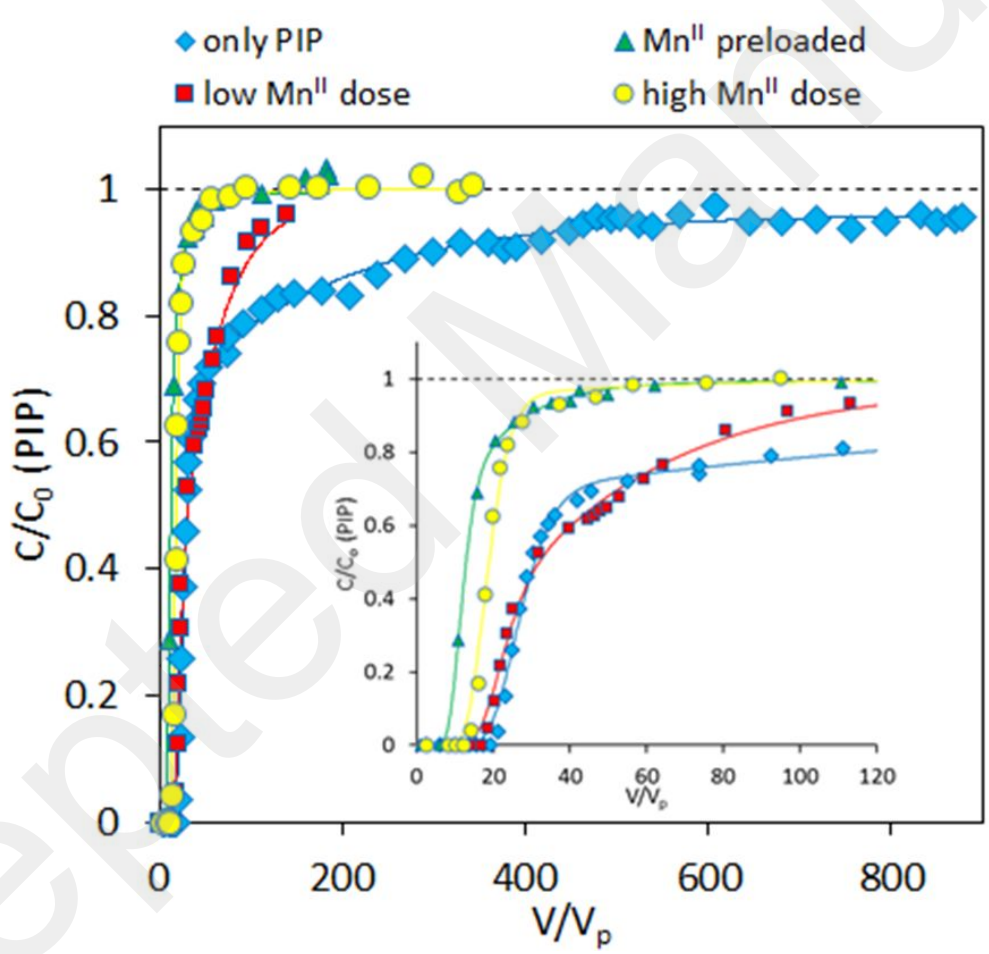

455 Fig. 5: Experimental and modeling BTCs of PIP for all experiments. Solid line represents the calculated BTCs. Dashed line indicate theoretical complete breakthrough $\left(\mathrm{C} / \mathrm{C}_{0}=1\right)$.

\section{Environmental Implications}

contaminants from percolating into the groundwater sources in both natural soils and artificial 
462 infiltration systems. We notably demonstrated that the reactivity of MCS can be strongly affected 463 through reductive dissolution of birnessite and binding of reduced ions to $\mathrm{MnO}_{2}$ surfaces. The 464 presence of dissolved $\mathrm{Mn}^{\mathrm{II}}$ frequently found in shallow groundwater, soil pore waters and surface 465 waters, can also alter surface reactivity and ultimately suppress the oxidative ability of birnessite. 466 The amount of dissolved $\mathrm{Mn}^{\mathrm{II}}$ available to compete with PIP for binding at the edge sites is the 467 driving factor, but this effect depends on the experimental setup (static batch vs continuous 468 dynamic flow). When a high amount of $\mathrm{Mn}^{\mathrm{II}}$ is contacted with $\mathrm{MnO}_{2}$ surfaces through preloading 469 or by increasing the inflow concentration, $\mathrm{Mn}^{\mathrm{II}}$ will interact first with edge sites and later diffuse 470 to the vacancy sites, but both sites will be occupied due to continuous supply of $\mathrm{Mn}^{\mathrm{II}}$ in column 471 experiments. Under these dynamic flow conditions, competition between PIP and $\mathrm{Mn}^{\mathrm{II}}$ to edges 472 sites take place over the whole reaction time. However, under static batch conditions where the 473 aqueous concentration of species depletes over time, competition between PIP and $\mathrm{Mn}^{\mathrm{II}}$ to edges 474 sites is supposed to take place only during the first kinetic stage. Using reactive transport modeling, 475 the estimated parameters are changed when column is previously loaded with $\mathrm{Mn}^{\mathrm{II}}$, suggesting the 476 modification of adsorption/oxidation mechanisms of PIP. Taken together, this work sheds light on 477 an overlooked aspect of manganese-mediated redox reactions in presence of reduced ions and 478 under flow-through conditions.

479 The implication of this work for environmental processes is twofold. First, the outcomes 480 of this investigation will help in developing fate and transport models of quinolones in natural systems (e.g. groundwater and subsurface environments). Second, they are also pertinent for 482 applications of MCS in engineered infiltration systems of contaminated waters (wastewater, 483 stormwater, agricultural runoff, etc.). Our efforts aid to show various scenarios on how the 484 feasibility and longevity of using MCS as a geomedia in such systems may fail. For example, 485 contacting a high amount of $\mathrm{Mn}^{\mathrm{II}}$ with MCS before or simultaneously with target compound leads 
to faster suppression of the MCS oxidative ability. Furthermore, flow interruption (or extremely

487 low pore-water velocities and low Péclet number where diffusion dominates over advection) could 488 trigger accelerated heterogeneous redox reactions to transform quinolones with MCS, but 489 simultaneously generate large amounts of $\mathrm{Mn}^{\mathrm{II}}$ to progressively diminish MCS reactivity. These 490 observations could help to design MCS based treatment systems with great longevity. For instance, 491 (electro)coagulation or oxidation and filtration systems prior to treatment with the MCS geomedia 492 could be proposed as a potential solution to remove the dissolved $\mathrm{Mn}^{\mathrm{II}}$. Second, coupling water 493 flow interruption with an in situ regeneration (e.g. using chlorine based oxidant or manganese494 oxidizing microbes) of passivated MCS geomedia could increase both efficiency and longevity of 495 manganese oxides based treatment systems. Finally, increasing the number of available reactive 496 sites of MCS by increasing the coating density could further aid in developing effective systems 497 for remediation of organic contamination.

\section{Supporting Information}

Methods: Synthesis of acid birnessite, procedure to clean quartz sand, bromide tracer 501 experiments, oxalic acid-permanganate back-titration method, detection of pipemidic acid and byproducts by chromatographic analysis, batch experiments, isotherm experiments, model 503 approach, and reaction mechanism of PIP and $\mathrm{MnO}_{2}$. Figures: XRD of AB, SEM and TEM images of $\mathrm{AB}$ and $\mathrm{MCS}$, experimental and calculated bromide tracer breakthrough curve, sorption isotherm with MCS, sorption isotherm and ATR-FTIR with acid birnessite, PIP and PIP $_{\text {ox }}$ molecular 506 structure, batch kinetic study, and SEM/EDAS imaging of MCS. Table: Parameters of PIP transport under step-injection conditions. 
This work was supported by the Institut Universitaire de France (IUF) and Région respectively. Finally, we thank the three anonymous reviewers for their constructive comments.

\section{References}

1. Weist, K.; Högberg, L. D., ECDC publishes 2015 surveillance data on antimicrobial resistance and antimicrobial consumption in Europe. Euro Surveill 2016, 21, (46), 30401.

$520 \quad 2 . \quad$ Ma, Y.; Li, M.; Wu, M.; Li, Z.; Liu, X., Occurrences and regional distributions of 20 antibiotics in water bodies during groundwater recharge. Science of The Total Environment 2015, 518-519, 498-506.

3. Lindberg, R. H.; Olofsson, U.; Rendahl, P.; Johansson, M. I.; Tysklind, M.; Andersson, B. A. V., Behavior of Fluoroquinolones and Trimethoprim during Mechanical, Chemical, and Active Sludge Treatment of Sewage Water and Digestion of Sludge. Environmental Science \& Technology 2006, 40, (3), 1042-1048.

4. WHO Pharmaceuticals in Drinking-water. WHO/HSE/WSH/11.05 World Health Organization, Geneva, 2011, 2011.

5. Golet, E. M.; Xifra, I.; Siegrist, H.; Alder, A. C.; Giger, W., Environmental Exposure Assessment of Fluoroquinolone Antibacterial Agents from Sewage to Soil. Environmental Science \& Technology 2003, 37, (15), 3243-3249.

6. Golet, E. M.; Alder, A. C.; Giger, W., Environmental Exposure and Risk Assessment of Fluoroquinolone Antibacterial Agents in Wastewater and River Water of the Glatt Valley Watershed, Switzerland. Environmental Science \& Technology 2002, 36, (17), 3645-3651.

533

7. Post, J. E., Manganese oxide minerals: Crystal structures and economic and environmental significance. Proceedings of the National Academy of Sciences 1999, 96, (7), 3447-3454.

8. Sims, J. L.; Patrick, W. H., The Distribution of Micronutrient Cations in Soil Under Conditions of Varying Redox Potential and pH1. Soil Science Society of America Journal 1978, 42, (2), 258-262.

9. Johnson, K.; Purvis, G.; Lopez-Capel, E.; Peacock, C.; Gray, N.; Wagner, T.; März, C.; Bowen, L.; Ojeda, J.; Finlay, N.; Robertson, S.; Worrall, F.; Greenwell, C., Towards a mechanistic understanding of carbon stabilization in manganese oxides. Nature Communications 2015, 6, (1), 7628.

10. Jiang, W.-T.; Chang, P.-H.; Wang, Y.-S.; Tsai, Y.; Jean, J.-S.; Li, Z.; Krukowski, K., Removal of ciprofloxacin from water by birnessite. Journal of Hazardous Materials 2013, 250-251, 362-369.

11. Remucal, C. K.; Ginder-Vogel, M., A critical review of the reactivity of manganese oxides with organic contaminants. Environmental Science: Processes \& Impacts 2014, 16, (6), 1247-1266.

$545 \quad 12 . \quad$ Li, Y.; Wei, D.; Du, Y., Oxidative transformation of levofloxacin by $\delta-M n O 2$ : Products, pathways and 546 toxicity assessment. Chemosphere 2015, 119, 282-288. 
13. Zhang, H.; Huang, C.-H., Oxidative Transformation of Fluoroquinolone Antibacterial Agents and

Structurally Related Amines by Manganese Oxide. Environmental Science \& Technology 2005, 39, (12), 4474-4483.

14. Charbonnet, J. A.; Duan, Y.; van Genuchten, C. M.; Sedlak, D. L., Chemical Regeneration of

Manganese Oxide-Coated Sand for Oxidation of Organic Stormwater Contaminants. Environmental Science \& Technology 2018, 52, (18), 10728-10736. oxide geomedia for passive urban stormwater treatment systems. Water Research 2016, 88, 481-491.

16. Balgooyen, S.; Campagnola, G.; Remucal, C. K.; Ginder-Vogel, M., Impact of bisphenol A influent concentration and reaction time on $\mathrm{MnO} 2$ transformation in a stirred flow reactor. Environmental Science: Processes \& Impacts 2019, 21, (1), 19-27.

17. Deng, J.; Ge, Y.; Tan, C.; Wang, H.; Li, Q.; Zhou, S.; Zhang, K., Degradation of ciprofloxacin using $\alpha-$ $\mathrm{MnO} 2$ activated peroxymonosulfate process: Effect of water constituents, degradation intermediates and toxicity evaluation. Chemical Engineering Journal 2017, 330, 1390-1400.

18. Lefkowitz, J. P.; Rouff, A. A.; Elzinga, E. J., Influence of pH on the Reductive Transformation of Birnessite by Aqueous Mn(II). Environmental Science \& Technology 2013, 47, (18), 10364-10371.

19. Zhao, H.; Zhu, M.; Li, W.; Elzinga, E. J.; Villalobos, M.; Liu, F.; Zhang, J.; Feng, X.; Sparks, D. L., Redox Reactions between $\mathrm{Mn}(\mathrm{II})$ and Hexagonal Birnessite Change Its Layer Symmetry. Environmental Science \& Technology 2016, 50, (4), 1750-1758.

20. Bargar, J. R.; Tebo, B. M.; Bergmann, U.; Webb, S. M.; Glatzel, P.; Chiu, V. Q.; Villalobos, M., Biotic and abiotic products of $\mathrm{Mn}$ (II) oxidation by spores of the marine Bacillus sp. strain SG-1. American Mineralogist 2005, 90, (1), 143-154.

21. Zhu, M.-X.; Wang, Z.; Xu, S.-H.; Li, T., Decolorization of methylene blue by $\delta$-MnO2-coated montmorillonite complexes: Emphasizing redox reactivity of Mn-oxide coatings. Journal of Hazardous Materials 2010, 181, (1), 57-64.

22. Lefkowitz, J. P.; Elzinga, E. J., Impacts of Aqueous Mn(II) on the Sorption of $\mathrm{Zn}(\mathrm{II})$ by Hexagonal Birnessite. Environmental Science \& Technology 2015, 49, (8), 4886-4893.

23. Elzinga, E. J.; Kustka, A. B., A Mn-54 Radiotracer Study of Mn Isotope Solid-Liquid Exchange during Reductive Transformation of Vernadite $(\delta-\mathrm{MnO} 2)$ by Aqueous $\mathrm{Mn}(\mathrm{II})$. Environmental Science \& Technology 2015, 49, (7), 4310-4316.

24. Hinkle, M. A. G.; Dye, K. G.; Catalano, J. G., Impact of Mn(II)-Manganese Oxide Reactions on Ni and Zn Speciation. Environmental Science \& Technology 2017, 51, (6), 3187-3196.

25. Elzinga, E. J., Reductive Transformation of Birnessite by Aqueous Mn(II). Environmental Science \& Technology 2011, 45, (15), 6366-6372.

26. Johnson, J. E.; Savalia, P.; Davis, R.; Kocar, B. D.; Webb, S. M.; Nealson, K. H.; Fischer, W. W., RealTime Manganese Phase Dynamics during Biological and Abiotic Manganese Oxide Reduction. Environmental Science \& Technology 2016, 50, (8), 4248-4258.

27. Ehlert, K.; Mikutta, C.; Kretzschmar, R., Impact of Birnessite on Arsenic and Iron Speciation during Microbial Reduction of Arsenic-Bearing Ferrihydrite. Environmental Science \& Technology 2014, 48, (19), 11320-11329.

28. Villalobos, M.; Lanson, B.; Manceau, A.; Toner, B.; Sposito, G., Structural model for the biogenic Mn oxide produced by Pseudomonas putida. American Mineralogist 2006, 91, (4), 489-502.

29. Shimizu, M.; Nakamura, S.; Takase, Y.; Kurobe, N., Pipemidic Acid: Absorption, Distribution, and Excretion. Antimicrobial Agents and Chemotherapy 1975, 7, (4), 441-446.

30. Doula, M. K., Simultaneous removal of $\mathrm{Cu}, \mathrm{Mn}$ and $\mathrm{Zn}$ from drinking water with the use of clinoptilolite and its Fe-modified form. Water Research 2009, 43, (15), 3659-3672.

31. Manzano, M.; Ayora, C.; Domenech, C.; Navarrete, P.; Garralon, A.; Turrero, M.-J., The impact of the Aznalcóllar mine tailing spill on groundwater. Science of The Total Environment 1999, 242, (1), 189209. 
32. Hem, J. D., Study and Interpretation of the Chemical Characteristics of Natural Water. US Geological Survey Water-Supply Paper 2254. 263 p. U.S. Geological Survey, Washington, DC. 1989.

33. McKenzie, R. M., The synthesis of birnessite, cryptomelane, and some other oxides and hydroxides of manganese. Mineralogical Magazine 1971, 38, (296), 493-502.

34. Kijima, N.; Yasuda, H.; Sato, T.; Yoshimura, Y., Preparation and Characterization of Open Tunnel Oxide $\alpha-\mathrm{MnO} 2$ Precipitated by Ozone Oxidation. Journal of Solid State Chemistry 2001, 159, (1), 94-102.

35. Georgiadis, A.; Thilo, R., A simple method to produce birnessiteâ?]? plant nutrition and soil science 2017, 180, (4), 491-495.

36. Zhou, L.; Martin, S.; Cheng, W.; Lassabatere, L.; Boily, J.-F.; Hanna, K., Water Flow Variability Affects Adsorption and Oxidation of Ciprofloxacin onto Hematite. Environmental Science \& Technology 2019, 53, (17), 10102-10109.

37. Padilla, I. Y.; Yeh, T.-C. J.; Conklin, M. H., The effect of water content on solute transport in unsaturated porous media. Water Resources Research 1999, 35, (11), 3303-3313.

38. Tye, A. M.; Young, S. D.; Crout, N. M. J.; Zhang, H.; Preston, S.; Barbosa-Jefferson, V. L.; Davison, W.; McGrath, S. P.; Paton, G. I.; Kilham, K.; Resende, L., Predicting the activity of $\mathrm{Cd} 2+$ and $\mathrm{Zn} 2+$ in soil pore water from the radio-labile metal fraction. Geochimica et Cosmochimica Acta 2003, 67, (3), 375-385.

39. van Genuchten, M. T.; Wagenet, R. J., Two-Site/Two-Region Models for Pesticide Transport and Degradation: Theoretical Development and Analytical Solutions. Soil Science Society of America Journal 1989, 53, (5), 1303-1310.

40. Brusseau, M. L.; Rao, P. S. C.; Jessup, R. E.; Davidson, J. M., Flow interruption: A method for investigating sorption nonequilibrium. Journal of Contaminant Hydrology 1989, 4, (3), 223-240.

41. Brusseau, M. L.; Hu, Q.; Srivastava, R., Using flow interruption to identify factors causing nonideal contaminant transport. Journal of Contaminant Hydrology 1997, 24, (3), 205-219.

42. Wang, P.; He, Y.-L.; Huang, C.-H., Oxidation of fluoroquinolone antibiotics and structurally related amines by chlorine dioxide: Reaction kinetics, product and pathway evaluation. Water Research 2010, 44, (20), 5989-5998.

43. Lafferty, B. J.; Ginder-Vogel, M.; Sparks, D. L., Arsenite Oxidation by a Poorly-Crystalline Manganese Oxide. 3. Arsenic and Manganese Desorption. Environmental Science \& Technology 2011, 45, (21), 9218-9223.

44. Zhu, M.; Ginder-Vogel, M.; Parikh, S. J.; Feng, X.-H.; Sparks, D. L., Cation Effects on the Layer Structure of Biogenic Mn-Oxides. Environmental Science \& Technology 2010, 44, (12), 4465-4471.

45. Drits, V. A.; Silvester, E.; Gorshkov, A. I.; Manceau, A., Structure of synthetic monoclinic Na-rich birnessite and hexagonal birnessite: I. Results from X-ray diffraction and selected-area electron diffraction. American Mineralogist 1997, 82, (9-10), 946.

46. Villalobos, M., The Role of Surface Edge Sites in Metal(loid) Sorption to Poorly-Crystalline Birnessites. In Advances in the Environmental Biogeochemistry of Manganese Oxides, American Chemical Society: 2015; Vol. 1197, pp 65-87.

47. Lafferty, B. J.; Ginder-Vogel, M.; Sparks, D. L., Arsenite Oxidation by a Poorly Crystalline Manganese-Oxide 1. Stirred-Flow Experiments. Environmental Science \& Technology 2010, 44, (22), 84608466.

48. Tournassat, C.; Charlet, L.; Bosbach, D.; Manceau, A., Arsenic(III) Oxidation by Birnessite and Precipitation of Manganese(II) Arsenate. Environmental Science \& Technology 2002, 36, (3), 493-500.

49. Lafferty, B. J.; Ginder-Vogel, M.; Zhu, M.; Livi, K. J. T.; Sparks, D. L., Arsenite Oxidation by a Poorly Crystalline Manganese-Oxide. 2. Results from X-ray Absorption Spectroscopy and X-ray Diffraction. Environmental Science \& Technology 2010, 44, (22), 8467-8472.

50. Yao, W.; Millero, F. J., Adsorption of Phosphate on Manganese Dioxide in Seawater. Environmental Science \& Technology 1996, 30, (2), 536-541. 
643 51. Manceau, A.; Lanson, M.; Geoffroy, N., Natural speciation of Ni, Zn, Ba, and As in ferromanganese 644 coatings on quartz using X-ray fluorescence, absorption, and diffraction. Geochimica et Cosmochimica Acta 645 2007, 71, (1), 95-128.

$64652 . \quad$ Peacock, C. L.; Sherman, D. M., Sorption of Ni by birnessite: Equilibrium controls on Ni in seawater. 647 Chemical Geology 2007, 238, (1), 94-106.

648 53. Manceau, A.; Lanson, B.; Drits, V. A., Structure of heavy metal sorbed birnessite. Part III: Results 649 from powder and polarized extended X-ray absorption fine structure spectroscopy. Geochimica et 650 Cosmochimica Acta 2002, 66, (15), 2639-2663.

651 54. Simanova, A. A.; Peña, J., Time-Resolved Investigation of Cobalt Oxidation by Mn(III)-Rich $\delta$-MnO2 652 Using Quick X-ray Absorption Spectroscopy. Environmental Science \& Technology 2015, 49, (18), 1086765310876.

654 55. Wang, Y.; Benkaddour, S.; Marafatto, F. F.; Peña, J., Diffusion- and pH-Dependent Reactivity of 655 Layer-Type MnO2: Reactions at Particle Edges versus Vacancy Sites. Environmental Science \& Technology $6562018,52,(6), 3476-3485$.

657 56. Cuprys, A.; Pulicharla, R.; Brar, S. K.; Drogui, P.; Verma, M.; Surampalli, R. Y., Fluoroquinolones 658 metal complexation and its environmental impacts. Coordination Chemistry Reviews 2018, 376, 46-61.

659 57. Holguera, J. G.; Etui, I. D.; Jensen, L. H. S.; Peña, J., Contaminant loading and competitive access of $660 \mathrm{~Pb}, \mathrm{Zn}$ and $\mathrm{Mn}(\mathrm{III})$ to vacancy sites in biogenic MnO2. Chemical Geology 2018, 502, 76-87. 